\section{This week in therapeutics}

Target/marker/

Indication

$$
\text { pathway }
$$

\section{Cancer}

Lung cancer; liver cancer
MicroRNA-221 (miR-221); miR222; phosphatase and tensin homolog deleted on chromosome ten (PTEN; MMAC1; TEP1); tissue inhibitor of metalloproteinases 3 (TIMP3); tumor necrosis factorrelated apoptosisinducing ligand (TRAIL)

\section{Summary}

Studies in cell culture suggest that inhibiting miR-221 and miR-222 could help treat lung and liver cancers. In human non-small cell lung cancer (NSCLC) and hepatocellular carcinoma (HCC) cells, increased miR-221 and miR-222 levels were associated with reduced expression of the tumor suppressors PTEN and TIMP3. Cancer cells with low expression of miR-221 and miR-222 had greater TRAIL-induced cell death than those with higher expression of the two miRNAs. Next steps include determining whether liver cancer can be induced via liver-specific overexpression of miR-221 and miR-222.

SciBX 3(1); doi:10.1038/scibx.2010.10

Published online Jan. 7, 2010

\title{
Publication and
} Licensing status contact information

Patent application filed; licensing status undisclosed
Garofalo, M. et al. Cancer Cell; published online Dec. 7, 2009; doi:10.1016/j.ccr.2009.10.014 Contact: Carlo Maria Croce, Ohio State University, Columbus, Ohio

e-mail: carlo.croce@osumc.edu Contact: Gerolama Condorelli, University of Naples, Naples, Italy e-mail: gecondor@unina.it 